\title{
Distribution of 3-Ketolactose Formation among Sphingomonas spp. and Other Members of the Alpha Subclass of the Proteobacteria
}

\author{
TAKESHI SAKANE, ${ }^{1 *}$ MARIKO TAKEUCHI, ${ }^{1}$ ANDRE DE BRUYN,${ }^{2}$ \\ KAREL KERSTERS, ${ }^{3}$ AND AKIRA YOKOTA ${ }^{1} \dagger$ \\ Institute for Fermentation, Osaka, Yodogawa-ku, Osaka 532, Japan, ${ }^{1}$ and Laboratorium voor Organische Chemie, ${ }^{2}$ \\ and Laboratorium voor Microbiologie, ${ }^{3}$ Rijkuniversiteit Gent, B-9000 Ghent, Belgium
}

\begin{abstract}
The distribution of 3-ketolactose formation among members of the alpha subclass of the Proteobacteria was investigated by the Benedict reagent test and by a more sensitive quantitative method in which high-performance liquid chromatography was used. 3-Ketolactose formation activity was found in strains of Agrobacterium biovar 1 and in strains of eight species of the genus Sphingomonas, including Sphingomonas paucimobilis (the type species), which belong to the alpha-2 and alpha-4 subclasses of the Proteobacteria, respectively. Weak activity was found in Erythrobacter longus IFO $14126^{\mathrm{T}}$ ( $\mathrm{T}=$ type strain), a member of the alpha-4 subclass of the Proteobacteria. The ketosugar was not produced by members of the other taxa of the alpha subclass of the Proteobacteria tested. The ketosugar was isolated from culture broths of $S$. paucimobilis IFO $13935^{\mathrm{T}}$ and Sphingomonas yanoikuyae IFO $15102^{\mathrm{T}}$ and was identified as 3-ketolactose [4- $O$-( $\beta$-D-xylo-hexopyranosyl-3ulose)-D-glucopyranose] by chromatographic analyses and ${ }^{1} \mathrm{H}$ nuclear magnetic resonance spectroscopy.
\end{abstract}

Formation of 3-ketolactose $(3 \mathrm{KL})$ [4-O-( $\beta$-D-xylo-hexopyranosyl-3-ulose)-D-glucopyranose] from lactose is characteristic of strains of Agrobacterium biovar 1 and has been widely used as a taxonomic marker to differentiate distinct biovar groups of the genus Agrobacterium (3-6, 11, 13). This reaction has been reported to be catalyzed by a hexopyranoside:cytochrome $c$ oxidoreductase (EC 1.1.99.13) (25). The structure of 3KL was elucidated by nuclear magnetic resonance (NMR) spectroscopy (100 MHz) and polarography in 1969 (1). Recently, the NMR spectrum of $3 \mathrm{KL}$ was completely analyzed at $500 \mathrm{MHz}$ by two-dimensional NMR techniques (7).

Holmes and Roberts (9) found that strains of the so-called "Agrobacterium yellow group" are also positive in the 3KL test, although DNA-rRNA hybridization experiments revealed that these bacteria are more closely related to Sphingomonas capsulata than to the genus Agrobacterium $(2,8)$. During studies on strains isolated from roots of plants, we found that certain yellow-pigmented bacteria were positive in the $3 \mathrm{KL}$ test and that these organisms could be classified in the genus Sphingomonas on the basis of biochemical and chemotaxonomic characteristics.

The genus Sphingomonas was proposed by Yabuuchi et al. (28) for yellow-pigmented, nonfermentative, gram-negative rods. These bacteria contain large amounts of a unique sphingoglycolipid and ubiquinone 10 and have high DNA $\mathrm{G}+\mathrm{C}$ contents (62 to $68 \mathrm{~mol} \%$ ). Members of the genus Agrobacterium are known to belong to the alpha-2 subclass of the Proteobacteria $(21,26)$, whereas members of the genus Sphingomonas belong to the alpha-4 subclass (24). Thus far, formation of $3 \mathrm{KL}$ from lactose has been thought to be a characteristic property of biovar 1 of the genus Agrobacterium, and this activity has not been found in any other taxon previously.

In this paper we describe the production of $3 \mathrm{KL}$ by members of the genus Sphingomonas and the distribution of 3KL-pro-

\footnotetext{
* Corresponding author. Mailing address: Institute for Fermentation, Osaka, 17-85, Juso-honmachi 2-chome, Yodogawa-ku, Osaka 532, Japan. Phone: 81-6-300-6555. Fax: 81-6-300-6814.

$\uparrow$ Present address: Institute of Molecular and Cellular Biosciences, The University of Tokyo, Bunkyo-ku, Tokyo 113, Japan.
}

ducing activity among members of the alpha subclass of the Proteobacteria.

\section{MATERIALS AND METHODS}

Bacterial strains. The strains belonging to the genus Sphingomonas examined in this study are listed in Table 1 . Three of the five strains previously classified as members of the "Agrobacterium yellow group" by Holmes and Roberts (9) (IFO $15208^{\mathrm{T}}$ [T = type strain], IFO 15209 , and IFO 15210) were obtained from the National Collection of Plant Pathogenic Bacteria, Harpenden, England, where they are deposited under the name [Agrobacterium rhizogenes], and two strains (IFO 15163 and IFO 15164) were obtained from the National Collection of Type Cultures, London, England, where they are deposited under the name [Chromobacterium lividum]. Three strains that were isolated from roots of rice plants and paddy soil (IFO 15495, IFO 15496, and IFO 15497) were obtained from J. Sugiyama, Institute of Molecular and Cellular Biosciences. The University of Tokyo, Tokyo, Japan; these strains were identified as Alcaligenes sp. strains. The origins of the 44 reference strains belonging to the alpha subclass of the Proteobacteria used in this study are shown in Table 2 .

3KL formation from lactose. All of the bacterial strains except Erthrobacter longus IFO $14126^{\mathrm{T}}$ and Roseobacter denitrificans IFO $15277^{\mathrm{T}}$ were grown on a solid medium containing $1 \%$ Bacto Yeast Extract (Difco), $2 \%$ glucose, $2 \%$ calcium carbonate, and $2 \%$ agar in deionized water for 2 to 4 days at $30^{\circ} \mathrm{C}$. Three loopfuls of cells were inoculated into $30 \mathrm{ml}$ of $\mathrm{YL}$ broth $(0.1 \%$ Bacto Yeast Extract and $1 \%$ lactose in deionized water; $\mathrm{pH} 6.8$ ) and incubated with rotary shaking for 3 days at $30^{\circ} \mathrm{C}$. E. longus IFO $14126^{\mathrm{T}}$ and Roseobacter denitrificans IFO $15277^{\mathrm{T}}$, which were isolated from seaweed, were grown in the same media prepared with $75 \%$ seawater instead of deionized water and incubated at $24^{\circ} \mathrm{C}$. After cells were removed by centrifugation, the culture broths were assayed for 3KL.

Detection of 3KL. $3 \mathrm{KL}$ was detected by adding $0.2 \mathrm{ml}$ of the Benedict reagent to $1 \mathrm{ml}$ of culture broth. After incubation for $60 \mathrm{~min}$ at room temperature $(25$ to $28^{\circ} \mathrm{C}$ ), each mixture was examined for the formation of yellow precipitates of $\mathrm{Cu}_{2} \mathrm{O}$ resulting from reaction with $3 \mathrm{KL}$. $3 \mathrm{KL}$ and other sugars were identified by the method of Mikami and Ishida (16), except that compounds were eluted with $0.4 \mathrm{M}$ boric acid-KOH buffer ( $\mathrm{pH} 9.0$ ); a model LC-9A high-performance liquid chromatography (HPLC) apparatus (Shimadzu) equipped a Shim-pac ISA O7/ S2504 column ( 250 by $4 \mathrm{~mm}$ ) and a Shimadzu model RF 10A spectrofluorometer was used for this analysis. 3KL purified from culture broth of Agrobacterium radiobacter IFO $13532^{\mathrm{T}}$ (biovar 1 ) was used as the standard.

Purification of $3 \mathrm{KL}$. Pure $3 \mathrm{KL}$ was isolated from $500-\mathrm{ml}$ portions of 5-day culture broths of $A$. radiobacter IFO $13532^{\mathrm{T}}$, Sphingomonas paucimobilis IFO $13935^{\mathrm{T}}$, and Sphingomonas yanoikuyae IFO $15102^{\mathrm{T}}$. After cells were removed, each supernatant was freeze-dried, and the dried material was dissolved in a small amount of water. Then 3 volumes of ethanol and 1 volume of a chloroformisoamyl alcohol mixture $(24: 1, \mathrm{vol} / \mathrm{vol})$ were added, and the solution was centrifuged. After the supernatant was treated with $\mathrm{IR} 120\left(\mathrm{H}^{+}\right)$ion exchange resin and then with IR $45\left(\mathrm{OH}^{-}\right)$ion exchange resin, the filtrate was concentrated to a syrup. The ketosugar was precipitated by adding methanol and keeping the solution in a refrigerator. Recrystallization from methanol was repeated to purify the ketosugar. 
TABLE 1. Strains of Sphingomonas species used

\begin{tabular}{|c|c|c|c|c|}
\hline Species & IFO no. ${ }^{a}$ & Obtained from $^{b}:$ & Source & Reference \\
\hline S. adhaesiva & $15099^{\mathrm{T}}$ & $\mathrm{JCM} 7370^{\mathrm{T}}$ & Water & 28 \\
\hline S. asaccharolytica & $15499^{\mathrm{T}}$ & Yasuda, as isolate $\mathrm{Y}-345^{\mathrm{T}}$ & Root of apple tree & \\
\hline S. capsulata & $12533^{\mathrm{T}}$ & ATCC $14666^{\mathrm{T}}$ & Water & 28 \\
\hline S. macrogoltabidus & $15033^{\mathrm{T}}$ & & Soil & 22 \\
\hline \multirow[t]{3}{*}{ S. mali } & $15500^{\mathrm{T}}$ & Yasuda, as isolate $\mathrm{Y}-347^{\mathrm{T}}$ & Root of apple tree & \\
\hline & 15501 & Yasuda, as isolate Y-348 & Root of apple tree & \\
\hline & 15502 & Yasuda, as isolate Y-351 & Root of apple tree & \\
\hline S. parapaucimobilis & $15100^{\mathrm{T}}$ & $\mathrm{JCM} 7510^{\mathrm{T}}$ & Urine & 28 \\
\hline \multirow[t]{4}{*}{ S. paucimobilis } & $13935^{\mathrm{T}}$ & JCM $7516^{\mathrm{T}}$ & Hospital respirator & 28 \\
\hline & 15495 & Sugiyama, as Alcaligenes sp. strain OGS47 & Paddy soil & 18 \\
\hline & 15496 & Sugiyama, as Alcaligenes sp. strain Y- 22 & Paddy soil & 18 \\
\hline & 15497 & Sugiyama, as Alcaligenes sp. strain Y-39 & Root of rice plant & 18 \\
\hline S. pruni & $15498^{\mathrm{T}}$ & Yasuda, as isolate $\mathrm{Y}-250^{\mathrm{T}}$ & Root of peach tree & \\
\hline \multirow[t]{3}{*}{ S. rosa } & $15208^{\mathrm{T}}$ & NCPPB $2661^{\mathrm{T}}$, as [A. rhizogenes] & Hairy root of Rosa sp. & 9 \\
\hline & 15209 & NCPPB 2662 , as $[A$. rhizogenes $]$ & Hairy root of Rosa sp. & 9 \\
\hline & 15210 & NCPPB 2663 , as [A. rhizogenes $]$ & Hairy root of Rosa sp. & 9 \\
\hline S. sanguis & $13937^{\mathrm{T}}$ & JCM $7514^{\mathrm{T}}$ & Blood & 22 \\
\hline S. terrae & $15098^{\mathrm{T}}$ & & Soil & 22 \\
\hline \multirow[t]{3}{*}{ S. yanoikuyae } & $15102^{\mathrm{T}}$ & $\mathrm{JCM} 7371^{\mathrm{T}}$ & Clinical specimen & 28 \\
\hline & 15163 & NCTC 10590 , as $[C$. lividum $]$ & Psychotria nairobiensis & 9 \\
\hline & 15164 & NCTC 10591 , as [C. lividum] & Tissue culture of Ardisia crispa & 9 \\
\hline
\end{tabular}

${ }^{a}$ IFO, Institute for Fermentation, Osaka, Yodogawa-ku, Osaka, Japan.

${ }^{b}$ JCM, Japan Collection of Microorganisms, RIKEN, Wako, Saitama, Japan; ATCC, American Type Culture Collection, Rockville, Md.; NCTC, National Collection of Type Cultures, London, England; NCPPB, National Collection of Plant Pathogenic Bacteria, Hatching Green, Harpenden, England; Sugiyama, J. Sugiyama, Institute of Molecular and Cellular Biosciences, The University of Tokyo, Tokyo, Japan; Yasuda, M. Yasuda, Fruit Tree Research Station, Ministry of Agriculture, Forestry and Fisheries, Tsukuba, Japan.

Identification of $3 \mathrm{KL}$. Thin-layer chromatography was performed by using cellulose thin layers (SPOTFILM S205; Tokyo Kasei Kogyo Co., Ltd.) and ethyl acetate-pyridine-acetic acid-water ( $5: 5: 1: 3$, by volume) as the developing solvent, followed by spraying with $1 \%$ triphenyltetrazolium chloride (TTC) in $0.5 \mathrm{~N}$ $\mathrm{NaOH} .{ }^{1} \mathrm{H}$ NMR spectra of the $3 \mathrm{KL}$ samples (in $\mathrm{D}_{2} \mathrm{O}$ ) were obtained at $20^{\circ} \mathrm{C}$ with a Bruker model AM500 spectrometer operating at $500.12 \mathrm{MHz}$ by using a pulse angle of $19^{\circ}$ and a resolution of $0.33 \mathrm{~Hz}$ per point. These spectra were analyzed by comparing them with the data of De Bruyn and Van Beeumen (7), which were obtained from two-dimensional NMR experiments performed at 500 $\mathrm{MHz}$.

\section{RESULTS AND DISCUSSION}

Formation of 3KL in Sphingomonas species. The results of the experiments to determine production of $3 \mathrm{KL}$ by the 21 Sphingomonas strains examined are shown in Table 3. A total of 15 strains, including $3 S$. paucimobilis strains, 1 Sphingomonas parapaucimobilis strain, $3 S$. yanoikuyae strains, 1 Sphingomonas asaccharolytica strain, 3 Sphingomonas mali strains, 1 Sphingomonas pruni strain, and 3 Sphingomonas rosa strains, were $3 \mathrm{KL}$ positive as determined by detection with the Benedict reagent, and $3 \mathrm{KL}$ concentrations of 0.15 to $2.4 \mathrm{mg} / \mathrm{ml}$ were found when the culture broths were analyzed by HPLC. Two strains, S. paucimobilis IFO 15497 and Sphingomonas sanguis IFO $13937^{\mathrm{T}}$, gave negative results with the Benedict reagent, but $3 \mathrm{KL}$ was detected at low concentrations $(0.03$ and 0.02 $\mathrm{mg} / \mathrm{ml}$, respectively) in the culture broths of these organisms by HPLC (Table 3). Thus, 17 strains belonging to eight Sphingomonas species produced 3KL from lactose. Four Sphingomonas strains, Sphingomonas adhaesiva IFO $15099^{\mathrm{T}}$, S. capsulata IFO $12533^{\mathrm{T}}$, Sphingomonas macrogoltabidus IFO $15033^{\mathrm{T}}$, and Sphingomonas terrae IFO $15098^{\mathrm{T}}$, were negative for $3 \mathrm{KL}$ production.

The eight strains isolated from plants and paddy soil and the misclassified strains [A. rhizogenes] IFO $15208^{\mathrm{T}}$, IFO 15209 , and IFO 15210 and [C. lividum] IFO 15163 and IFO 15164, which were assigned to the Agrobacterium yellow group by Holmes and Roberts (9), have been found to belong to the genus Sphingomonas on the basis of the following biochemical and chemotaxonomic characteristics: production of yellow pigment, presence of ubiquinone Q-10 and large amounts of sphingolipid, presence of 2-hydroxy fatty acids but not 3-hydroxy acids as cellular hydroxy fatty acids, and DNA G+C contents of 64.0 to $65.9 \mathrm{~mol} \%$. The biochemical and chemotaxonomic characteristics of these strains are described in the accompanying paper (23). Of these 13 strains, 3 (IFO 15495, IFO 15496 , and IFO 15497) were identified as $S$. paucimobilis, and 2 (IFO 15163 and IFO 15164) were identified as $S$. yanoikuyae. The remaining eight strains differed from the previously described species of the genus Sphingomonas and are described as Sphingomonas rosa, Sphingomonas pruni, Sphingomonas asaccharolytica, and Sphingomonas mali (Table 1) in the accompanying paper (23).

The changes in the $3 \mathrm{KL}$ concentrations in culture broths during cultivation of six strains of Sphingomonas species and $A$. radiobacter IFO $13532^{\mathrm{T}}$ are shown in Table 4 . In the culture broth of $A$. radiobacter IFO $13532^{\mathrm{T}}$, about $60 \%$ of the initial lactose was oxidized to $3 \mathrm{KL}$ after incubation for 1 day, and the concentration of the accumulated $3 \mathrm{KL}$ decreased slightly after 4 days of incubation. Although this strain was $o$-nitrophenyl$\beta$-D-galactopyranoside test positive (data not shown), neither glucose nor galactose was found in the culture broth. A similar change in sugar content was found in the culture broth of $S$. yanoikuyae IFO 15163, but the amount of 3KL produced was about one-half that produced by $A$. radiobacter IFO $13532^{\mathrm{T}}$. Lactose was catabolized slowly by $S$. rosa IFO $15208^{\mathrm{T}}$, but the amount of $3 \mathrm{KL}$ in the culture broth increased when the incubation time was increased to 4 days. Small amounts of $3 \mathrm{KL}$ and large amounts of glucose and galactose accumulated in the culture broths of $S$. pruni IFO $15498^{\mathrm{T}}, S$. asaccharolytica IFO $15499^{\mathrm{T}}$, and $S$. mali IFO $15500^{\mathrm{T}}$. After incubation for 4 days, the amounts of $3 \mathrm{KL}$ in these cultures were 12 to $23 \%$ of the amounts found after 1 day of incubation, whereas the concentrations of glucose and galactose had increased. No $3 \mathrm{KL}$ was detected at any time in the culture broth of $S$. capsulata IFO $12533^{\mathrm{T}}$. These results indicate that during incubation $3 \mathrm{KL}$ pro- 
TABLE 2. 3KL formation in members of the alpha subclass of the Proteobacteria

\begin{tabular}{|c|c|c|c|c|c|c|c|}
\hline \multirow{2}{*}{ Species $^{a}$} & \multirow{2}{*}{$\begin{array}{l}\text { IFO } \\
\text { no. }^{b}\end{array}$} & \multirow{2}{*}{$\begin{array}{c}\text { Original } \\
\text { designation }\end{array}$} & \multirow{2}{*}{$\begin{array}{c}\text { Detection by } \\
\text { Benedict reagent }\end{array}$} & \multicolumn{4}{|c|}{ Amt of sugar $(\mathrm{mg} / \mathrm{ml})$ as determined by HPLC } \\
\hline & & & & $3 \mathrm{KL}$ & Lactose & Glucose & Galactose \\
\hline \multicolumn{8}{|l|}{ Alpha-1 subclass } \\
\hline Aquaspirillum polymorphum & $13961^{\mathrm{T}}$ & ATCC $11332^{\mathrm{T}}$ & - & $-^{e}$ & 9.53 & 0.03 & 0.16 \\
\hline Azorhizobium caulinodans & $14845^{\mathrm{T}}$ & LMG $6465^{\mathrm{T}}$ & - & - & 6.55 & - & 0.28 \\
\hline Rhodospirillum rubrum & 3986 & & - & - & 9.89 & - & 0.02 \\
\hline \multicolumn{8}{|l|}{ Alpha-2 subclass } \\
\hline Agrobacterium radiobacter (biovar 1) & $13532^{\mathrm{T}}$ & ATCC $19358^{\mathrm{T}}$ & +++ & 9.09 & 0.19 & - & - \\
\hline Agrobacterium rhizogenes (biovar 1) & 14554 & NIAES 1724 & +++ & 8.02 & 0.06 & 0.01 & 0.01 \\
\hline Agrobacterium rhizogenes (biovar 2) & $13257^{\mathrm{T}}$ & ATCC $11325^{\mathrm{T}}$ & - & - & 4.41 & - & - \\
\hline Agrobacterium rubi & $13261^{\mathrm{T}}$ & ATCC $13335^{\mathrm{T}}$ & - & - & 5.66 & 0.02 & - \\
\hline Agrobacterium tumefaciens (biovar 1) & 13264 & ATCC 11157 & +++ & 6.17 & 2.10 & - & 0.01 \\
\hline Agrobacterium tumefaciens (biovar 2) & 15196 & SAES R-6 & - & - & 9.57 & - & - \\
\hline Agrobacterium vitis (biovar 3) & $15140^{\mathrm{T}}$ & NCPPB $3554^{\mathrm{T}}$ & - & - & 5.87 & 0.01 & - \\
\hline Beijerinckia indica & 3744 & ATCC 9037 & - & - & 9.80 & - & - \\
\hline Bradyrhizobium japonicum & $14783^{\mathrm{T}}$ & ATCC $10324^{\mathrm{T}}$ & - & - & 6.65 & - & - \\
\hline Brevundimonas diminuta & $12697^{\mathrm{T}}$ & ATCC $11568^{\mathrm{T}}$ & - & - & 9.50 & 0.05 & 0.02 \\
\hline Brevundimonas vesicularis & $12165^{\mathrm{T}}$ & ATCC $11426^{\mathrm{T}}$ & & & 8.93 & - & - \\
\hline Mycoplana bullata & $13290^{\mathrm{T}}$ & ATCC $4278^{\mathrm{T}}$ & - & - & 10.05 & - & 0.03 \\
\hline Mycoplana dimorpha & $13291^{\mathbf{T}}$ & ATCC $4279^{\mathrm{T}}$ & - & - & 10.07 & - & - \\
\hline Mycoplana ramosa & $15249^{\mathrm{T}}$ & NCIB $9440^{\mathrm{T}}$ & - & - & 10.01 & - & - \\
\hline Rhizobium fredii & $14780^{\mathrm{T}}$ & ATCC $35423^{\mathrm{T}}$ & - & - & 5.77 & 0.04 & 0.25 \\
\hline Rhizobium galegae & $14965^{\mathrm{T}}$ & HAMBI $540^{\mathrm{T}}$ & - & - & 6.36 & - & 0.19 \\
\hline Rhizobium huakuii & $15243^{\mathrm{T}}$ & CCBAU $2609^{\mathrm{T}}$ & - & - & 6.08 & - & - \\
\hline Rhizobium leguminosarum & $14778^{\mathrm{T}}$ & ATCC $10004^{\mathrm{T}}$ & - & - & 4.43 & - & - \\
\hline Rhizobium loti & $14779^{\mathrm{T}}$ & ATCC $33669^{\mathrm{T}}$ & - & - & 5.90 & - & - \\
\hline Rhizobium meliloti & $14782^{\mathrm{T}}$ & ATCC $9930^{\mathrm{T}}$ & - & - & 2.70 & 3.55 & 3.58 \\
\hline Rhizobium tropici & $15247^{\mathrm{T}}$ & CIAT $899^{\mathrm{T}}$ & - & - & 3.11 & - & - \\
\hline Thiobacillus novellus & $14993^{\mathrm{T}}$ & ATCC $8093^{\mathrm{T}}$ & - & - & 10.03 & - & - \\
\hline \multicolumn{8}{|l|}{ Alpha-3 subclass } \\
\hline Paracoccus denitrificans & 13301 & ATCC 19367 & - & - & 9.89 & - & - \\
\hline Rhodobacter sphaeroides & $12203^{\mathrm{T}}$ & NCIB $8253^{T}$ & - & - & 8.38 & - & 0.01 \\
\hline Roseobacter denitrificans & $15277^{\mathrm{T}}$ & Shiba, Och $101^{\mathrm{T}}$ & - & - & 5.55 & - & 0.49 \\
\hline Thiobacillus versutus & $14567^{\mathrm{T}}$ & ATCC $25364^{\mathrm{T}}$ & - & - & 9.65 & - & - \\
\hline \multicolumn{8}{|l|}{ Alpha-4 subclass } \\
\hline Blastobacter natatorius & $15649^{\mathrm{T}}$ & ATCC $35951^{\mathrm{T}}$ & - & - & 6.37 & 0.03 & 0.24 \\
\hline Erythrobacter longus & $14126^{\mathrm{T}}$ & Shiba, Och $101^{\mathrm{T}}$ & - & $\operatorname{tr}^{f}$ & 5.92 & 0.01 & 0.43 \\
\hline Rhizomonas suberifaciens & $15211^{\mathrm{T}}$ & NCPPB $3629^{\mathrm{T}}$ & - & - & 6.23 & - & - \\
\hline \multicolumn{8}{|l|}{ Alpha subclass } \\
\hline Acetobacter aceti & $14818^{\mathrm{T}}$ & NCIB $8621^{\mathrm{T}}$ & - & - & 10.05 & - & - \\
\hline Acetobacter hansenii & $14820^{\mathrm{T}}$ & NCIB $8746^{\mathrm{T}}$ & - & - & 10.08 & - & - \\
\hline Acetobacter liquefaciens & $12388^{\mathrm{T}}$ & IAM $1834^{\mathrm{T}}$ & - & - & 9.93 & - & - \\
\hline Acetobacter pasteurianus & 13752 & NCIB 8622 & - & $=$ & 10.05 & - & - \\
\hline Aquaspirillum itersonii & $15648^{\mathrm{T}}$ & ATCC $12639^{\mathrm{T}}$ & - & - & 9.96 & - & 0.01 \\
\hline Aquaspirillum peregrinum & $14922^{\mathrm{T}}$ & NCIB $9435^{\mathrm{T}}$ & - & - & 9.86 & 0.02 & 0.04 \\
\hline Gluconobacter asaii & $3276^{\mathrm{T}}$ & & - & - & 10.05 & - & - \\
\hline Gluconobacter cerinus & $3567^{\mathbf{T}}$ & & - & - & 10.07 & - & - \\
\hline Gluconobacter frateurii & $3264^{\mathrm{T}}$ & & - & - & 10.04 & - & - \\
\hline Gluconobacter oxydans & $14819^{\mathrm{T}}$ & NCIB $9013^{\mathrm{T}}$ & - & - & 10.06 & - & - \\
\hline Xanthobacter autotrophicus & 14758 & DSM 1618 & - & - & 9.74 & - & 0.02 \\
\hline Xanthobacter flavus & $14759^{\mathrm{T}}$ & DSM $338^{\mathrm{T}}$ & - & - & 9.34 & - & 0.09 \\
\hline
\end{tabular}

${ }^{a}$ Subclass assignments based on data from references $6,10,12,15,24,27$, and 29 .

${ }^{b}$ IFO, Institute for Fermentation, Osaka, Yodogawa-ku, Osaka, Japan.

c ATCC, American Type Culture Collection, Rockville, Md.; LMG, Culture Collection of the Laboratorium voor Microbiologie, Rijksuniversiteit Gent, Ghent, Belgium; NIAES, National Institute of Agro-Environmental Sciences, Ministry of Agriculture, Forestry and Fisheries, Tsukuba, Japan; SAES, Shizuoka Agricultural Experiment Station, Shizuoka, Japan; NCPPB, National Collection of Plant Pathogenic Bacteria, Hatching Green, Harpenden, England; HAMBI, Culture Collection of the Department of Microbiology, University of Helsinki, Helsinki, Finland; CCBAU, Culture Collection of Beijing Agricultural University, Beijing, People's Republic of China; CIAT, Centro de Investigacion sobre Fijacion de Nitrogeno, Universidad Nacional Autonoma de Mexico, Morelos, Mexico; NCIB, National Collection of Industrial Bacteria, Torrey Research Station, Aberdeen, Scotland; Shiba, T. Shiba, Ocean Research Institute, The University of Tokyo, Iwate, Japan; IAM, Microbial and Microalgal Research Center, Institute of Applied Microbiology, The University of Tokyo, Tokyo, Japan; DSM, Deutsche Sammlung von Mikroorganismen und Zellkulturen GmbH, Braunschweig, Germany.

$d+++$, strongly positive; - , negative.

$e_{-}$, not detected (concentration, $<0.003 \mathrm{mg} / \mathrm{ml}$ ).

$f_{\mathrm{tr}}$, trace $(0.003 \mathrm{mg} / \mathrm{ml})$.

duced from lactose is catabolized by Sphingomonas species as well as by agrobacteria (11).

Identification of $3 \mathrm{KL}$ produced by Sphingomonas species. The chemical characteristics of the ketosugars purified from the culture broths of $S$. paucimobilis IFO $13935^{\mathrm{T}}$ and $S$. yanoikuyae IFO $15102^{\mathrm{T}}$ were compared with the chemical characteristics of the ketosugar produced by $A$. radiobacter IFO $13532^{\mathrm{T}}$. These three ketosugars exhibited the same reten- 
TABLE 3. Production of $3 \mathrm{KL}$ and other sugars from lactose by members of the genus Sphingomonas and A. radiobacter

\begin{tabular}{|c|c|c|c|c|c|}
\hline \multirow{2}{*}{ Strain } & \multirow{2}{*}{$\begin{array}{c}\text { Detection by } \\
\text { Benedict reagent }{ }^{a}\end{array}$} & \multicolumn{4}{|c|}{ Amt of sugar $(\mathrm{mg} / \mathrm{ml})$ as determined by HPLC } \\
\hline & & $3 \mathrm{KL}$ & Lactose & Glucose & Galactose \\
\hline S. adhaesiva IFO $15099^{\mathrm{T}}$ & - & $-^{c}$ & 9.89 & - & - \\
\hline S. asaccharolytica IFO $15499^{\mathrm{T}}$ & w & 0.31 & 4.68 & 2.32 & 0.67 \\
\hline S. capsulata IFO $12533^{\mathrm{T}}$ & - & - & 1.16 & 0.01 & 0.02 \\
\hline S. macrogoltabidus IFO $15033^{\mathrm{T}}$ & - & - & 6.38 & 0.03 & 0.13 \\
\hline S. mali IFO $15500^{\mathrm{T}}$ & w & 0.26 & 4.55 & 2.37 & 1.07 \\
\hline S. mali IFO 15501 & w & 0.20 & 1.08 & 3.65 & 1.17 \\
\hline S. mali IFO 15502 & w & 0.18 & 5.06 & 1.95 & 0.91 \\
\hline S. parapaucimobilis IFO $15100^{\mathrm{T}}$ & w & 0.34 & 0.14 & 0.86 & 0.11 \\
\hline S. paucimobilis IFO $13935^{\mathrm{T}}$ & + & 1.25 & 0.07 & 2.08 & 0.29 \\
\hline S. paucimobilis IFO 15495 & $\mathrm{w}$ & 0.15 & 1.32 & 1.04 & 0.19 \\
\hline S. paucimobilis IFO 15496 & w & 0.18 & 2.93 & 0.73 & 0.43 \\
\hline S. paucimobilis IFO 15497 & - & 0.03 & 1.60 & 1.81 & 1.63 \\
\hline S. pruni IFO $15498^{\mathrm{T}}$ & w & 0.20 & 4.63 & 1.78 & 1.25 \\
\hline S. rosa IFO $15208^{\mathrm{T}}$ & + & 2.02 & 2.76 & - & - \\
\hline S. rosa IFO 15209 & + & 0.86 & 4.58 & - & 0.05 \\
\hline S. rosa IFO 15210 & + & 0.80 & 7.34 & 0.02 & - \\
\hline S. sanguis IFO $13937^{\mathrm{T}}$ & - & 0.02 & 1.12 & 2.31 & 0.34 \\
\hline S. terrae IFO $15098^{\mathrm{T}}$ & - & - & 6.12 & - & - \\
\hline S. yanoikuyae IFO $15102^{\mathrm{T}}$ & + & 2.40 & 4.36 & 0.07 & 0.02 \\
\hline S. yanoikuyae IFO 15163 & + & 2.02 & 3.53 & 0.16 & 0.14 \\
\hline S. yanoikuyae IFO 15164 & + & 2.32 & 3.63 & 0.17 & 0.17 \\
\hline A. radiobacter IFO $13532^{\mathrm{T}}$ & +++ & 5.94 & 0.12 & - & - \\
\hline
\end{tabular}

$a+++$, strongly positive; + , moderately positive; $w$, weakly positive; - , negative

${ }^{b}$ Small amounts of an unknown sugar(s) were also detected.

- not detected (concentration, $<0.003 \mathrm{mg} / \mathrm{ml}$ )

tion time (39.5 min) during HPLC and the same migration distance $\left(R_{f}, 0.28\right)$ on thin-layer chromatography preparations. All of the sugars gave positive reactions in the Benedict reagent and alkaline-TTC tests. The chemical shifts of the $3 \mathrm{KL}$ samples in $\mathrm{D}_{2} \mathrm{O}$ solutions were very close to the reference values (7) (Table 5), confirming the chemical structure of these compounds as $3 \mathrm{KL}$. When $3 \mathrm{KL}$ is crystallized from methanol, it exists as a hemiacetal with the $\mathrm{OCH}_{3}$ group equatorial (7).

Distribution of $3 \mathrm{KL}$ formation among members of the alpha subclass of the Proteobacteria. Table 2 summarizes the results of the Benedict reagent test and the sugar compositions (as determined by HPLC) of the culture broths of 44 strains belonging to the alpha subclass of the Proteobacteria. The alpha subclass has been divided into four subgroups, the alpha-1, alpha-2, alpha-3, and alpha-4 subgroups (27). 3KL was detected only in some members of the alpha- 2 and alpha- 4 subclasses. None of the members of the alpha- 1 and alpha-3 subclasses investigated formed $3 \mathrm{KL}$.

In the alpha- 2 subclass, $3 \mathrm{KL}$ was produced by Agrobacterium biovar 1 strains $A$. radiobacter IFO $13532^{\mathrm{T}}, A$. rhizogenes IFO
14554, and Agrobacterium tumefaciens IFO 13264, but 3KL was not found in the culture broths of other agrobacteria, including $A$. rhizogenes IFO $13257^{\mathrm{T}}$ (biovar 2), A. tumefaciens IFO 15196 (biovar 2), Agrobacterium vitis IFO $15140^{\mathrm{T}}$ (previously classified as a member of biovar 3) (17), and Agrobacterium rubi IFO $13261^{\mathrm{T}}$. Furthermore, the test for production of $3 \mathrm{KL}$ from lactose was negative with the following taxa belonging to the alpha-2 subclass: Beijerinckia indica, Bradyrhizobium japonicum, three species of the genus Mycoplana, two species of the genus Brevundimonas (previously assigned to the taxa Pseudomonas diminuta and Pseudomonas vesicularis) (20), seven species of the genus Rhizobium, and Thiobacillus novellus. E. longus IFO $14126^{\mathrm{T}}$, a member of the alpha-4 subclass, was weakly $3 \mathrm{KL}$ positive; although the culture broth of this strain exhibited a negative reaction in the Benedict reagent test, a trace of $3 \mathrm{KL}$ $(0.003 \mathrm{mg} / \mathrm{ml})$ was found in the culture broth. Blastobacter natatorius IFO $15649^{\mathrm{T}}$ and Rhizomonas suberifaciens IFO $15211^{\mathbf{T}}$, which are also members of the alpha-4 subclass $(10$, 24 ), did not produce $3 \mathrm{KL}$.

In conclusion, the $3 \mathrm{KL}$-producing bacteria belonging to the

TABLE 4. Changes in sugar contents of lactose-containing culture broths during cultivation of Sphingomonas and $A$. radiobacter strains

\begin{tabular}{|c|c|c|c|c|c|c|c|c|}
\hline \multirow{3}{*}{ Strain } & \multicolumn{8}{|c|}{ Amt of sugar $(\mathrm{mg} / \mathrm{ml})$ as determined by HPLC after: } \\
\hline & \multicolumn{4}{|c|}{1 day } & \multicolumn{4}{|c|}{4 days } \\
\hline & $3 \mathrm{KL}$ & Lactose & Glucose & Galactose & $3 \mathrm{KL}$ & Lactose & Glucose & Galactose \\
\hline S. yanoikuyae IFO 15163 & 3.02 & 1.88 & $-a$ & - & 2.16 & - & - & - \\
\hline S. rosa IFO $15208^{\mathrm{T}}$ & 1.44 & 5.80 & - & - & 1.88 & 1.64 & - & - \\
\hline S. pruni IFO $15498^{\mathrm{T}}$ & 0.66 & 4.38 & 0.60 & 0.28 & 0.08 & 0.09 & 2.83 & 1.22 \\
\hline S. asaccharolytica IFO $15499^{\mathrm{T}}$ & 0.88 & 4.63 & 1.68 & 0.37 & 0.16 & 0.72 & 4.03 & 0.95 \\
\hline S. mali IFO $15500^{\mathrm{T}}$ & 0.35 & 5.13 & 1.42 & 0.53 & 0.08 & 0.82 & 3.92 & 0.94 \\
\hline S. capsulata IFO $12533^{\mathrm{T}}$ & - & 3.67 & 0.02 & 0.05 & - & 0.35 & - & - \\
\hline A. radiobacter IFO $13532^{\mathrm{T}}$ & 5.98 & 1.11 & - & - & 5.58 & 0.50 & - & - \\
\hline
\end{tabular}

${ }^{a}-$, not detected (concentration, $<0.003 \mathrm{mg} / \mathrm{ml}$ ). 
TABLE 5. ${ }^{1} \mathrm{H}$ NMR chemical shifts of $3 \mathrm{KL}$ in $\mathrm{D}_{2} \mathrm{O}$

\begin{tabular}{|c|c|c|c|c|}
\hline \multirow[b]{2}{*}{ Moiety } & \multirow{2}{*}{$\begin{array}{l}\text { Reference value } \\
\qquad(\mathrm{ppm})^{a}\end{array}$} & \multicolumn{3}{|c|}{ Chemical shift (ppm) with $3 \mathrm{KL}$ formed by: } \\
\hline & & $\begin{array}{l}\text { A. radiobacter } \\
\text { IFO } 13532^{\mathrm{T}}\end{array}$ & $\begin{array}{l}\text { S. paucimobilis } \\
\text { IFO } 13935^{\mathrm{T}}\end{array}$ & $\begin{array}{l}\text { S. yanoikuyae } \\
\text { IFO } 15102^{\mathrm{T}}\end{array}$ \\
\hline \multicolumn{5}{|c|}{$\beta$-D-xylo-Hexopyranosyl-3-ulose moieties } \\
\hline $\mathrm{H}-1^{\prime}$ & 4.57 & 4.54 & 4.54 & 4.54 \\
\hline $\mathrm{H}-2^{\prime}$ & 3.61 & 3.57 & 3.57 & 3.57 \\
\hline $\mathrm{H}-4^{\prime}$ & 3.66 & 3.63 & 3.64 & 3.64 \\
\hline $\mathrm{H}-5^{\prime}$ & 3.99 & 3.97 & 3.97 & 3.97 \\
\hline $\mathrm{H}-6^{\prime} \mathrm{A}$ & 3.78 & 3.75 & 3.75 & 3.76 \\
\hline$H-6^{\prime} B$ & 3.78 & 3.75 & 3.75 & 3.76 \\
\hline $\mathrm{OCH}_{3}$ (acetal) & 3.37 & 3.35 & 3.35 & 3.35 \\
\hline \multicolumn{5}{|c|}{$\alpha$-D-Glucopyranosyl moieties } \\
\hline H-1 & 5.25 & 5.22 & 5.21 & 5.21 \\
\hline $\mathrm{H}-2$ & 3.60 & 3.57 & 3.57 & 3.57 \\
\hline H-3 & 3.85 & 3.83 & 3.83 & 3.84 \\
\hline H-4 & 3.67 & 3.66 & 3.65 & 3.65 \\
\hline H-5 & 3.96 & 3.93 & 3.94 & 3.93 \\
\hline H-6A & 3.90 & 3.87 & 3.88 & 3.88 \\
\hline H-6B & 3.90 & 3.87 & 3.88 & 3.88 \\
\hline \multicolumn{5}{|c|}{$\beta$-D-Glucopyranosyl moieties } \\
\hline $\mathrm{H}-1$ & 4.68 & 4.65 & 4.66 & 4.66 \\
\hline $\mathrm{H}-2$ & 3.31 & 3.28 & 3.28 & 3.28 \\
\hline H-3 & 3.67 & 3.65 & 3.67 & 3.67 \\
\hline $\mathrm{H}-4$ & 3.67 & 3.65 & 3.67 & 3.67 \\
\hline $\mathrm{H}-5$ & 3.64 & 3.60 & 3.60 & 3.60 \\
\hline $\mathrm{H}-6 \mathrm{~A}$ & 3.97 & 3.95 & 3.94 & 3.95 \\
\hline $\mathrm{H}-6 \mathrm{~B}$ & 3.84 & 3.82 & 3.83 & 3.83 \\
\hline
\end{tabular}

${ }^{a}$ Data from reference 7 .

alpha subclass of the Proteobacteria were members of the alpha- 2 and alpha- 4 subclasses. The $3 \mathrm{KL}$-positive bacteria belonging to the alpha-2 subclass were restricted to strains of Agrobacterium biovar 1 , as reported previously $(6,14)$. The 3KL-positive members of the alpha- 4 subclass were members of eight species of the genus Sphingomonas, including $S$. paucimobilis (the type species), and E. longus. On the basis of $16 \mathrm{~S}$ rRNA gene sequences, Takeuchi et al. have suggested that the genus Sphingomonas is a heterogeneous taxon that can be divided into several subgroups (24). The 3KL-positive species of the genus Sphingomonas were distributed among some of the subgroups of Takeuchi et al. (24). It seems that the erratic distribution of $3 \mathrm{KL}$ formation is due to horizontal gene transfer or plasmid-mediated gene transfer. However, the relationship between $3 \mathrm{KL}$ production and the taxonomic positions of bacteria is not yet clear. Furthermore, although 3KL-positive bacteria have been isolated from various sources, including plants, soil, and clinical specimens $(19,27)$, little information about the physical role of the enzyme in these organisms is available.

\section{REFERENCES}

1. Anteunis, M., J. Van Beeumen, A. De Bruyn, and J. De Ley. 1969. N.M.R. experiments on acetals. XIX. The N.M.R. analysis and structure of 3-ketolactose and $\beta$-D-galactose. Bull. Soc. Chim. Belg. 78:651-658.

2. Bauwens, M., and J. De Ley. 1981. Improvements in the taxonomy of Flavobacterium by DNA:rRNA hybridization, p. 27-31. In $\mathrm{H}$. Reichenbach and O. B. Weeks (ed.), The Flavobacterium-Cytophaga group. Verlag Chemie, Weinheim, Germany.

3. Bernaerts, M. J., and J. De Ley. 1958. 3-Ketoglycosides, new intermediates in the bacterial catabolism of disaccharides. Biochim. Biophys. Acta 30:661664.

4. Bernaerts, M. J., and J. De Ley. 1960. Microbiological formation and preparation of 3-ketoglycosides from disaccharides. J. Gen. Microbiol. 22:129_ 136.

5. Bernaerts, M. J., and J. De Ley. 1960. The structure of 3-ketoglycosides formed from disaccharides by certain bacteria. J. Gen. Microbiol. 22:137146.

6. Bernaerts, M. J., and J. De Ley. 1963. A biochemical test for crown gall bacteria. Nature (London) 197:406-407.

7. De Bruyn, A., and J. Van Beeumen. 1992. Structure of "3-ketolactose" [4-O-(beta-D-xylo-hexopyranosyl-3-ulose)-D-glucopyranose] by ${ }^{1} \mathrm{H}$ - and ${ }^{13} \mathrm{C}$ n.m.r. spectroscopy. Carbohydr. Res. 228:445-449.

8. De Ley, J., P. Segers, and M. Gillis. 1978. Intra- and intergeneric similarities of Chromobacterium and Janthinobacterium ribosomal ribonucleic acid cistrons. Int. J. Syst. Bacteriol. 28:154-168.

9. Holmes, B., and P. Roberts. 1981. The classification, identification and nomenclature of agrobacteria. J. Appl. Bacteriol. 50:443-467.

10. Hugenholtz, P., E. Stackebrandt, and J. A. Fuerst. 1994. A phylogenetic analysis of the genus Blastobacter with a view to its future reclassification. Syst. Appl. Microbiol. 17:51-57.

11. Janssens, D., K. Kersters, and J. De Ley. 1983. The catabolism of 3-ketolactose in Agrobacterium. Syst. Appl. Microbiol. 4:155-168.

12. Katayama, Y., A. Hiraishi, and H. Kuraishi. 1994. Phylogeny of facultatively chemolithotrophic thiobacilli with ubiquinone-10. Nippon Nogeikagaku Kaishi 68:670. (In Japanese.)

13. Kersters, K., and J. De Ley. 1984. Genus III. Agrobacterium Conn 1942, p. 244-254. In N. R. Krieg and J. G. Holt (ed.), Bergey's manual of systematic bacteriology, vol. 1. The Williams \& Wilkins Co., Baltimore.

14. Kersters, K., J. De Ley, P. H. A. Sneath, and M. Sackin. 1973. Numerical taxonomic analysis of Agrobacterium. J. Gen. Microbiol, 78:227-239.

15. Lane, D. J., A. P. Harrison, Jr., D. Stahl, B. Pace, S. J. Giovannoni, G. J. Olsen, and N. R. Pace. 1992. Evolutionary relationships among sulfur- and iron-oxidizing eubacteria. J. Bacteriol. 174:269-278.

16. Mikami, H., and Y. Ishida. 1983. Post-column fluorometric detection of reducing sugars in high-performance liquid chromatography using arginine. Bunseki Kagaku 32:E207-E210.

17. Ophel, K., and A. Kerr. 1990. Agrobacterium vitis sp. nov, for strains of Agrobacterium biovar 3 from grapevines. Int. J. Syst. Bacteriol. 40:236-241.

18. Oyaizu-Masuchi, Y., and K. Komagata. 1988. Isolation of free-living nitrogen-fixing bacteria from the rhizosphere of rice. J. Gen. Appl. Microbiol. 34:127-164.

19. Potvliege, C., L. Vanhuynegem, and W. Hansen. 1989. Catheter infection caused by an unusual pathogen, Agrobacterium radiobacter. J. Clin. Microbiol. 27:2120-2122.

20. Segers, P., M. Vancanneyt, B. Pot, U. Torck, B. Hoste, D. Dewettinck, E. Falsen, K. Kersters, and P. De Vos. 1994. Classification of Pseudomonas diminuta Leifson and Hugh 1954 and Pseudomonas vesicularis Busing, Doll, and Freytag 1953 in Brevundimonas gen. nov. as Brevundimonas diminuta comb. nov. and Brevundimonas vesicularis comb. nov., respectively. Int. J. Syst. Bacteriol. 44:499-510.

21. Stackebrandt, E., R. G. E. Murray, and H. G. Trüper. 1988. Proteobacteria classis nov., a name for the phylogenetic taxon that includes the "purple 
bacteria and their relatives." Int. J. Syst. Bacteriol. 38:321-325.

22. Takeuchi, M., F. Kawai, Y. Shimada, and A. Yokota. 1993. Taxonomic study of polyethylene glycol-utilizing bacteria: emended description of the genus Sphingomonas and new descriptions of Sphingomonas macrogoltabidus sp. nov., Sphingomonas sanguis sp. nov. and Sphingomonas terrae sp. nov. Syst. Appl. Microbiol. 16:227-238.

23. Takeuchi, M., T. Sakane, M. Yanagi, K. Yamasato, K. Hamana, and A Yokota. 1995. Taxonomic study of bacteria isolated from plants: proposals of Sphingomonas rosa sp. nov., Sphingomonas pruni sp. nov., Sphingomonas asacchrolytica sp. nov., and Sphingomonas mali sp. nov. Int. J. Syst. Bacteriol. 45:334-341.

24. Takeuchi, M., H. Sawada, H. Oyaizu, and A. Yokota. 1994. Phylogenetic evidence for Sphingomonas and Rhizomonas as nonphotosynthetic members of the alpha-4 subclass of the Proteobacteria. Int. J. Syst. Bacteriol. 44:308314.

25. Van Beeumen, J., and J. De Ley. 1968. Hexopyranoside: cytochrome c oxidoreductase from Agrobacterium tumefaciens. Eur. J. Biochem. 6:331-343.
26. Willems, A., and M. D. Collins. 1993. Phylogenetic analysis of rhizobia and agrobacteria based on 16S rRNA sequences. Int. J. Syst. Bacteriol. 43:305313.

27. Woese, C. R., E. Stackebrandt, W. G. Weisburg, B. J. Paster, M. T. Madigan, V. J. Fowler, C. M. Hahn, P. Blanz, R. Gupter, K. H. Nealson, and G. E. Fox. 1984. The phylogeny of purple bacteria: the alpha subdivision. Syst. Appl. Microbiol. 5:315-326.

28. Yabuuchi, E., I. Yano, H. Oyaizu, Y. Hashimoto, T. Ezaki, and H. Yamamoto. 1990. Proposals of Sphingomonas paucimobilis gen. nov. and comb. nov., Sphingomonas parapaucimobilis sp. nov., Sphingomonas yanoikuyae sp. nov., Sphingomonas adhaesiva sp. nov., Sphingomonas capsulato comb. nov., and two genospecies of the genus Sphingomonas. Microbiol. Immunol. 34:99-119.

29. Yanagi, M., and K. Yamasato. 1993. Phylogenetic analysis of the family Rhizobiaceae and related bacteria by sequencing of 16 S rRNA gene using PCR and DNA sequencer. FEMS Microbiol. Lett. 107:115-120. 